\title{
Jogos Olímpicos de Berlim 1936: o uso do esporte para fins nada esportivos
}

\author{
Olympics Berlin 1936: \\ the use of sport for non-sportive ends
}

Filipe Fernandes Ribeiro Mostaro I filipemostaro@hotmail.com

Possui graduação em Comunicação Social pela Universidade Federal de Juiz de Fora (2006), especialização em Jornalismo Esportivo e Negócios do Esporte pela FACHA-IGEC-RJ (2012). Atuou por 5 anos na Rádio Universitária da UFJF. Foi bolsista do Sport Club Juiz de Fora em 2002. Por 4 anos atuou como Editor de VT no Estúdio da Faculdade de Comunicação da UFJF. Apresentou o programa

Desafio Esportivo na TV Alterosa de julho de 2010 a dezembro de 2010. Atualmente trabalha no

webprograma Comentário Miojo. Pesquisador do Núcleo em Comunicação, Esporte e Cultura, da

UFJF. Integra também o Grupo de Pesquisa Comunicação e Esporte, da Sociedade Brasileira de Estudos Interdisciplinares da Comunicação (Intercom). Autor do livro GARRINCHA X PELÉ: influência da mídia na carreira de um jogador (2012). Atua principalmente nos seguintes temas: comunicação com ênfase em Rádio, TV e Jornalismo Esportivo, Copas do Mundo e identidade nacional.

Resumo: O artigo mostra como a Alemanha nazista usou os Jogos Olímpicos de Berlim em 1936 para resgatar a autoestima do povo alemão, difundir seus dogmas e, principalmente, exaltar a raça ariana como superior. A maneira como o corpo ganhou importância na sociedade alemã da época, apontado no filme Olympia, demonstra que o esporte foi usado para disciplinar e preparar a juventude para a guerra que estava por vir e é um dos exemplos mais famosos de como os Jogos esporte podem ser usados para fins políticos e para exaltar um regime e um povo.

Palavras-chave: Esporte, Política, Nazismo, Olimpíadas.

Abstract: The article shows how Nazi Germany used the Berlin Olympics in 1936 to rescue the self-esteem of the German people, to spread their dogma, and especially to exalt the Aryan race as superior. The way the body has gained importance in German society at the time, pointed out in the fllm Olympia, demonstrates that the sport was used to discipline and prepare youth for the war that was to come and is one of the most famous examples of how games and sports can be used for political purposes and to exalt a regime and a people.

Keywords: Sports, Politics, Nazism, Olympicss. 


\section{Introdução}

O esporte é um dos maiores fenômenos socioculturais do mundo, segundo Tubino (2006), e, por esse motivo, está sempre em destaque na mídia, despertando a paixão de bilhôes de pessoas ao redor do mundo, independente de qual esporte a pessoa seja devoto. Esse fervor com que a atividade desportiva é acompanhada em todo nosso Planeta desperta interesses políticos. Segundo Murad (2005).

[...] todos os fenômenos sociais estão eivados de politica, inequivocamente. Desse modo, como um dos fatores da cultura humana relevante "fato social total", o esporte não está a margem desta constante estrutural; pelo contrário, são sempre mais ou menos visiveis suas interaçôes. (MURAD, 2005, p.75)

Aqui, deixamos claro que concordamos com as observaçôes de DaMatta (1979), de que o esporte não é o ópio do povo e não o deixa alienado. Mas, pode ser usado para difundir ideias e, em diferentes épocas, alguns governantes usaram o esporte para sua promoção e exaltaçáo de suas ideologias.

Um dos casos mais conhecidos foi a propaganda nazista durante os Jogos de Berlim em 1936. Hitler usou um evento mundial e de cunho não-político para mostrar a nova Alemanha que nascia depois da Primeira Guerra Mundial. A força do Estado, a capacidade de organização e, principalmente, a tentativa de demonstrar a superioridade da raça ariana foram amplamente divulgadas pela propaganda do partido nazista através dos jornais, rádio e cinema.

O filme Olympia transmite a importância e a exaltação do corpo ariano como obsessão dos nazistas. Até mesmo o "quadro de medalhas" foi divulgado pela primeira vez nesta disputa para demonstrar a supremacia alemã, mas o esporte sempre dá liçôes ao homem e Jesse Owens, um negro, expôs a Hitler e ao mundo que a raça ariana não era superior. Mesmo assim, a forma com que o governo de Hitler usou os Jogos marcou a história do esporte e mostrou o que seu uso indevido pode fazer.

\section{O esporte e a política}

O esporte sempre esteve presente na vida do homem e desde a época da Grécia Antiga, já tínhamos o Estado explorando os jogos para afirmação de ideias, ideologias e o culto ao corpo. Basta nos lembrarmos de Esparta, cidade-estado grega que treinava seus jovens dos 7 aos 21 anos para o serviço militar e dominou os Jogos Olímpicos Gregos, que eram realizados na cidade de Olympia nos arredores do templo de Zeus, revelando o caráter religioso do esporte. Os espartanos já usavam o esporte para preparação militar e todas as cidades-estado gregas aproveitaram-se dele para criar um sentido de identidade ao povo grego. Na Roma Antiga, os imperadores e o Senado também usaram o esporte para acalmar a população e diminuir as tensôes sociais, com os jogos no Coliseu, na tão famosa política do pão e circo (panis et circences). Lembrando que os jogos romanos eram disputas sangrentas entre os gladiadores e a execução de condenados, diferente dos esportes olímpicos gregos. 
No século XIX, foram criadas as Escolas Ginásticas que difundiram o esporte e pregavam a militarização e o nacionalismo exacerbado através do esporte. Com isso, a Educação Física começou a ser implantada nas escolas européias da época. Mais tarde, a Inglaterra, em meio à Revoluçáo Industrial, enxergou no esporte uma forma de disciplinar os trabalhadores e o difundiu pelo mundo, tornando-o popular, juntamente com as fábricas e as máquinas a vapor.

$O$ esporte moderno se desenvolveu paralelamente ao processo de industrialização herdando dele a racionalização, sistematização e a orientação ao resultado. A burguesia industrial inglesa usou habilmente os principios educativos do esporte para desenvolver junto à classe proletária valores como disciplina, hierarquia, rendimento. Assim, a regulamentação da prática esportiva dos trabalhadores atendeu aos interesses de doutrinação da burguesia, sob o pretexto da higienização e conseqüentemente da melhora da saúde. (SIGOLI; DE ROSE., 2004, p.111)

Com o domínio inglês sobre vários países, os ideais de esporte praticados por eles se expandiram pelo mundo e se tornaram um terreno fértil para a transformação dessa atividade em grande fenômeno social.

Já Rubio (2012), ressalta que o renascimento do interesse pelos estudos clássicos fez reviver nos intelectuais da época, o fascínio pela cultura helênica. A descoberta de sítios arqueológicos permitiu desvendar acontecimentos relacionados aos Jogos da Antiguidade. Tais fatos fizeram com que o pedagogo humanista barão Pierre de Coubertin, organizasse "uma instituição de caráter internacional com a finalidade de cuidar daquilo que seria uma atividade capaz de transformar a sociedade daquele momento: o esporte." (RUBIO, 2012, p.4). Ainda segundo Rubio:

A tarefa audaciosa de promover uma competição esportiva de âmbito internacional,
espelhada nos Jogos Olimpicos gregos, com caráter educativo e permanente
demandava a criação de uma instituição que desse o suporte humano e material
para a realização de tal empreitada. (...)E assim, em junho de 1894, na Sorbonne,
em Paris, diante de uma plateia que reunia aproximadamente duas mil pessoas,
das quais 79 representavam sociedades esportivas e universidades de 13 naçôes,
teve início o congresso esportivo-cultural, no qual Coubertin apresentou a proposta
de recriação dos Jogos Olimpicos. (RUBIO, 2012, p.6)

O chamado Olimpismo difundido por Coubertin tinha a ideia de um esporte amador e pregava a prática desinteressada das atividades esportivas, não sendo permitida a remuneração dos participantes em função de sua atuação esportiva. Segundo Salun (2012) "aos poucos, no século XX, a ideia inicial de confraternização foi substituída por uma visão de espetáculo e competição.” (SALUN, 2012, p.4)

Aliada à perda do "status" de atividade amadora, os ideários nacionalistas, que estavam em crescimento na Europa daquela época, transformaram os Jogos Olímpicos em defesa de uma Naçáo frente às outras, aflorando o sentimento patriótico dos cidadãos, com a exaltação de elementos simbólicos da pátria como bandeiras e hinos. "A participação, e até mesmo 
a interferência do Estado nos esportes, foi um fenômeno de escala mundial. As vitórias na esfera esportiva podiam ser interpretadas como simbologia do poderio da nação." (SALUN, 2012, p.3)

Salun(2012) afirma que nas primeiras décadas do século XX mudaram os ideais de Cobertin:

Os anos 1920 e 1930 foram marcos da explosão dos esportes como um fenômeno de massa ligado a um novo estilo de vida - urbanizado e dinâmico - que atingiu as regióes mais industrializadas do mundo. Essas regióes assistiram a uma revolução que tirou do esporte sua característica lúdica e o transformara em uma fábrica de competiçâo. (SALUN, 2012, p.3)

Com isso, os governos passaram a investir na preparação de seus atletas para provarem a superioridade da sua Nação. Desde então, os Jogos Olímpicos não representam apenas a confraternização entre os povos ou a busca de um melhor desenvolvimento humano, mas também a disputa de interesses políticos e econômicos de Estados e corporaçóes. $\mathrm{O}$ auge desse pensamento pode ser visto e analisado em nosso objeto de estudo: os Jogos Olímpicos de 1936 em Berlim, em meio ao crescimento das ideias e dogmas nazistas.

Os Jogos Olimpicos da era moderna propagaram o esporte por todo o mundo. Apesar
de este ter se tornado uma instituiçáo independente, continuou a ser apropriado por
estados nacionais e por outras instituiçóes. Este fato pôde ser observado na Alemanha
nazista durante os Jogos Olimpicos de Berlim, em 1936, e também durante toda a
Guerra Fria. (SIGOLI; DEROSE, 2004, p.112)

\section{A Alemanha nazista e o corpo bélico}

O povo alemão foi marcado por divisôes territoriais e políticas desde a época do império prussiano e sempre buscou um fator que os unisse. As ideias românticas de Goethe, um dos pais desse movimento, que rompiam com os dogmas iluministas da razão, colocou no povo alemão a crença de que podia existir a liberdade de pensamento e que as respostas para as perguntas estavam dentro deles mesmos. Isso fez com que os alemães voltassem os olhos para seu próprio país, despertando um sentimento de nacionalismo forte, que seria o ingrediente principal para as ideias de Hitler. Goethe queria, com seu movimento, romper com esquemas que regulavam as relaçôes individuais, sociais, políticas e morais.

As ideias de liberdade e ruptura com os antigos regimes e formas sociais ocorreram e a Alemanha precisava de um exército para fazer seu domínio valer. Necessitava também de um comandante com o dom divino para liderar esse povo para glória, já que os alemáes, segundo as crenças arianas, eram predestinados e enviados pelos deuses para comandar os outros povos. Nesse momento surge Otto Von Bismack, o imperador que uniu o povo alemáo, com a ajuda das ideias de seu compatriota Goethe. Ele expandiu as fronteiras alemãs através do poderio bélico e militar, conquistando regióes como Lorena, que era dominada pela França. O resultado foi a Primeira Guerra Mundial e a derrota 
alemã. E pior que a derrota foi o Tratado de Versalhes que feriu profundamente o orgulho da sociedade alemá, que acreditava ter nascido para liderar o mundo.

$O$ Tratado de Versalhes e as demais imposiçôes implantadas pelos aliados vitoriosos fizeram, novamente, a identidade da Alemanha cair em depressão. A nação foi obrigada a ceder treze por cento de seu território, a cindir a dinastia imperial, a separar-se da Áustria. Foram impostos a desmilitarização e o pagamento de indenizaçôes para os países envolvidos no conflito. A transição da monarquia para a república foi inspecionada pelos paises aliados e assim foi criada a República de Weimar. (FERREIRA, 2002, p.103)

Se o orgulho alemão estava ferido, o país precisava de outra maneira de se redescobrir e recuperar a autoestima. Neste momento entra em cena um pequeno partido político chamado Partido Nacional-Socialista dos Trabalhadores Alemães, o NSDAP, cuja sigla ficaria conhecida universalmente por Partido Nazista. Liderado por um amante das artes e ex-combatente do exército alemão na Primeira Guerra Mundial, Adolf Hitler, que aos poucos foi conseguindo difundir suas ideias totalitárias, semelhantes ao fascismo. O nazismo ganhou muita força após a Primeira Guerra Mundial. Era um movimento de extrema direita intensamente nacionalista, xenófobo, que incitava a violência militar e policial, antiliberal, antidemocrático, antiproletário e antisocialista. $\mathrm{Na}$ Alemanha, encontrou um ambiente fértil depois da humilhação que o povo alemão sofreu com o Tratado de Versalhes. Os dogmas nazistas vinham para confrontar o crescimento dos movimentos bolcheviques, inspirados na Revolução Russa, e que também ganharam força no pós Primeira Guerra. Além disso, a fraca democracia de Weimar perdeu popularidade ao esvaziar o poder histórico do Exército (o Reichswehr), dos grandes proprietários rurais (os Junkers) e das classes industriais abastadas. Isto somado ao descontentamento da classe média, temerosa com a ameaça da esquerda e com a perda de privilégios para a crescente onda socialista vinda da URSS, foram os pilares que Hitler e o partido nazista precisavam para construir seu império.

A ideia difundida era a mesma de Bismarck. Era um idealismo alemão achar que "na titânica luta entre as forças da luz e das trevas, o bem e o mal, o espírito e as riquezas, a salvação do mundo estava supostamente nas mãos da raça alemã" (STACKELBERG, 2002, p.80)

A Alemanha passara por um forte abalo financeiro em 1923 e com a Crise Mundial do Capitalismo em 1929, Hitler ganhou um combustível a mais para difundir suas ideias e chegar ao poder em 1933, pregando que somente um Estado forte e totalitário seria capaz de tirar a Alemanha da crise. Dessa forma, acabou com todos os outros partidos políticos e perseguiu seus críticos, principalmente o povo judeu.

O que Hitler tenta fazer é estabelecer diretrizes que retirem a alma alemã de suas dúvidas e façam com que a nação renasça. Isso significa que, diante das opçóes, ele escolhe uma e faz dela uma verdade. Ele escolhe beber na herança histórica deixada por Bismarck e retoma o ideal de guerra; ele escolhe o caminho da valorização dos 
super-homens e mexe na alma da nação. Ele transforma o Estado no início e no fim de toda preocupação da vida política, econômica, social, cultural, artística e militar. (FERREIRA, 2002, p.104)

Neste quadro político e social, Berlim foi candidata a sede dos Jogos Olímpicos de 1936 e com a promessa de construçóes gigantescas e uma infra-estrutura jamais vista em uma edição dos Jogos, ela venceu a disputa contra Barcelona. Foram 40 votos a favor, 16 contra e 80 abstençóes. Vale lembrar que já em 1916 o país seria a sede, porém, devido à suspensão dos Jogos por conta da Primeira Guerra, não o foi.

A realização dos Jogos Olímpicos seria utilizada para exaltar a honra do povo alemão, abalada pelas imposiçôes humilhantes do tratado de Versailles. No entanto, em 1936, os jogos acabaram representando os interesses de propaganda do governo totalitário nazista, e tornaram-se um marco de referência da utilização do esporte para fins politicos. (SIGOLI; DE ROSE., 2004, p.112)

Um possível boicote aos Jogos chegou a ser organizado pelos espanhóis que, juntamente com os países democráticos ocidentais, entre eles os EUA, não concordavam com o Governo de Hitler, principalmente com a sua perseguição ao povo judeu. Além disso, a Alemanha era apontada pelos aliados como a grande culpada pela Primeira Guerra Mundial. Naquela época o mesmo país sede dos Jogos Olímpicos de Verão sediava os Jogos Olímpicos de Inverno, portanto entre 2 e 16 de fevereiro de 1936, a Alemanha realizou, em Garmisch-Partenkirchen, os Jogos de Inverno. A essa altura, a infraestrutura para os Jogos de Verão, que começariam no dia primeiro de agosto, estava pronta. $\mathrm{O}$ tratamento dado às delegaçóes e aos jornalistas pelos nazistas foi bem recebido pela comunidade internacional. As placas ofensivas aos judeus foram retiradas pelo Governo, e, logo, a ideia de boicote foi se perdendo. $\mathrm{O}$ discurso usado foi de que as Olimpíadas eram dos atletas e não do Governo, mas na verdade, esta foi a Olimpíada de um Governo.

Hitler assumiu a organização dos Jogos e queria mostrar ao mundo, através das Olimpíadas, as maravilhas da Alemanha nazista e canalizar toda a vontade de renascimento do povo alemáo para o mundo. Para issotal convocou Goebbels e o seu Ministério de Propaganda para veicular a publicidade dos Jogos nazistas. Coube ao arquiteto Albert Speer, a responsabilidade de desenhar a reforma do Grünewald Stadium e a Vila Olímpica. O Exército Alemão entrou em cena para auxiliar nas obras dos conjuntos esportivos e da Vila Olímpica e os milhares de desempregados do país tiveram trabalho com a preparação para os Jogos.

A máquina do Estado Nazista organizou a melhor edição dos Jogos Olímpicos até então. A população foi orientada a receber bem os participantes. Os hotéis e restaurantes receberam a determinação de atender bem a todos relevando os preceitos racistas. Os jornais e boletins oficiais de perseguição aos judeus foram recolhidos. Os cartazes antisemitistas foram retirados dos locais públicos. O Exercito e a Policia Nazista S.A. ocuparam Berlim durante os jogos. A cidade foi decorada com bandeiras e pinturas ostentando os aros olimpicos e a suástica nazista. Hinos 
nazistas e olimpicos eram entoados a todo tempo nos alto-falantes instalados pela cidade. Imagens dos jogos foram reproduzidas em telóes espalhados pelas praças de Berlim. Durante os jogos, todas as açôes exaltavam a ordem e a glória do governo nazista do III Reich. As cerimônias, desfiles e uniformes deixavam a impressão militar e belicosa aparentes. (SIGOLI; DE ROSE, 2004, p.114)

Dentro deste panorama político, o esporte era uma maneira de educar o jovem e resgatar a autoestima do povo alemáo. A propaganda nazista se inspirava no povo grego e a ideia era reforçar a crença do ariano como raça pura. Ariano era o nome dado aos povos que invadiram o Peloponeso e deram origem às cidades gregas. E os alemães confiavam plenamente que eram os herdeiros dos gregos, tanto na beleza física, quanto na habilidade política e principalmente na arte da guerra. Eles acreditavam que deveriam liderar e salvar o mundo dos bárbaros e imperfeitos. Assim como em Esparta, o real propósito da educação nazista era incorporar um senso de disciplina, dever, obediência, coragem e serviço à causa nacional, segundo afirma o próprio Führer em seu "Minha Luta".

O jovem súdito da nação alemã é obrigado a receber a educação que se ministra a todos os alemães. Ele se submete assim à mesma educação dos nacionais. Mais tarde ele tem que se submeter à educação física oficial e, finalmente, entra para as fileiras do exército. O serviço militar é obrigatório. Deve abranger todos os alemães, a fim de prepará-los, física e espiritualmente, para as possiveis exigências militares. Depois do serviço militar, aos jovens, inteiramente sadios, com solenidade será concedido o título de cidadão. Esse será o mais importante documento para toda a sua vida. Ele entra na posse de todos os direitos e goza de todas as vantagens dai decorrentes. É preciso que se faça a diferença entre os que concorrem para a existência e grandeza da nação e os que residem no país apenas para ganhar a vida. A concessão do título de cidadão exige um solene juramento em relação à coletividade e ao Estado. Nesse título deve ser inscrito: Deve ser uma honra maior ser varredor de rua em sua Pátria do que rei em pais estrangeiro. O cidadão alemão é privilegiado em relação ao estrangeiro. Essa honra excepcional também implica em deveres. O individuo sem honra, sem caráter, o criminoso comum, o traidor da Pátria, etc., pode, em qualquer tempo, ser privado desses direitos. Tornase, então, súdito, novamente. (HITLER, 1925, p. 232)

Também dentro da doutrina grega do corpo, os nazistas se aproveitaram da ideia do ágon, que era o sacrifício total do corpo pela pólis. Sacrifício significa fazer algo sagrado, fazer algo que o deixe mais perto dos deuses, uma ideologia bastante messiânica e que coloca a pessoa disposta a tudo para conseguir seu objetivo. No caso do nazismo alemão, o corpo político se tornou um corpo bélico.

Quando Adolf Hitler escreveu o "Mein Kampf", ressalvou a importância dos esportes $e$ da Educação Física preconizando que, no pais, seis milhóes de corpos saudáveis poderiam formar um exército forte no futuro. Isso era um pensamento corrente entre políticos e até mesmo educadores em várias partes do mundo. (SALUN, 2012, p.8)

A escola do país e da sociedade era o Exército, maior representação do poderio alemão. Esse poder era exercido por soldados com os "corpos construídos" dentro do que a ideologia nazista pregava: os arianos puros descendentes e herdeiros da beleza helenística. (FERREIRA, 2002). O corpo grego e sua 
cultura eram, o tempo todo, exaltados na Alemanha nazista, principalmente em suas esculturas. "O culto ao corpo permitiu que Eva Braun, amante de Hitler, fosse filmada em seu convívio familiar exibindo sua aptidão na ginástica olímpica e na natação." (SALUN, 2012, p. 5). A Vila Olímpica foi toda construída nos moldes dos grandes bosques gregos, tudo para dar a sensação de que se estava na Grécia Antiga.

Esse corpo treinado e criado pelo Estado devia servir a ele e ganhar por ele, para elevar seu nome e confirmar a sua supremacia. Os valores individuais eram suplantados pelos coletivos e, a partir daquele momento a propaganda nazista começava a associar o sacrifício do atleta com o sacrifício humano dentro de uma guerra, explorando uma tradição de que morrer no campo de batalha era uma honraria para qualquer antepassado germânico. Desta forma Hitler conseguiu atrair os jovens para o Exército.

A crença do corpo perfeito e bélico já tinha sido bem difundida por Hitler e junto a ela a ideia de que somente o povo ariano tinha a herança histórica de reviver os gregos.

$O$ arianismo será um parâmetro para medir o grau de perfeição a que as pessoas poderiam chegar. Requisitava-se certificado de pureza de raça para se ingressar em qualquer atividade da vida pública, nas escolas e nos negócios, nas pesquisas científicas e nos consultórios médicos, nos nascimentos e nas unióes matrimoniais. (FERREIRA, 2002, p.107)

Com todos esses fatores, certamente que os considerados "não-arianos" (negros, ciganos e deficientes) não faziam parte do ideal nazista de perfeição. A Lei de Nuremberg organizou uma esterilizaçáo forçada de deficientes, perseguiu ciganos e negros, organizou a detenção de homossexuais e Testemunhas de Jeová e privou o povo judeu de sua cidadania. Se eles não tinham nem mesmo os direitos comuns da sociedade, quanto mais representar o país através do esporte. Durante a preparação para os Jogos a perseguição racial a esses povos só aumentou, mostrando que os cartazes retirados durante os Jogos de Inverno eram pura manipulação.

Duas semanas antes dos Jogos começarem, as autoridades alemãs informaram que Gretel Bergmann, uma atleta judia, estava fora da competição. Ela tinha uma das melhores marcas do mundo no salto em altura, mas foi recusada na equipe alemã, sacrificando até uma medalha. Entretanto, a medalha de nada valeria para a propaganda nazista se fosse conquistada por um não-ariano. Este episódio deu um aperitivo da propaganda política que seria feita. Outros atletas judeus e ciganos também foram excluídos da delegação alemã.

Os arredores de Berlim foram limpos, tirando ciganos, judeus e qualquer tipo de presença, sinal ou costume não-ariano. Houve uma camuflagem da Alemanha e por algumas semanas, apesar de toda a repressão, tentou-se passar a imagem de que todos eram respeitados, independente de sua etnia e raça.

No dia $1^{\circ}$ de agosto Hitler abriu os Jogos Olímpicos que ficariam para a História, não pelo esporte, mas porque, em 16 de agosto, quando eles 
terminaram, os 49 países participantes e os 3.963 atletas, sendo 3.632 homens e 331 mulheres, sabiam do que a propaganda nazista era capaz.

\section{A mídia nos Jogos e Olympia, o triunfo do corpo}

Segundo o próprio Führer: "A propaganda estimula a coletividade no sentido de uma ideia, preparando-a para a vitória da mesma; a organização tem de ganhar a vitória mediante concentraçáo dos adeptos corajosos, capazes de combater pelo triunfo comum." (HITLER, 1925, p.307) Ela deveria ser dirigida às grandes massas e não há como negar que a propaganda nazista foi muito bem realizada.

Até 1936 o povo alemão estava sendo preparado no terreno das ideias e o espírito alemão já estava pronto para a busca do seu espaço vital e consequentemente para a guerra. $\mathrm{O}$ rádio foi um veículo muito usado e decisivo nas propagaçóes desses dogmas. As transmissóes radiofônicas uniram o país através da língua e dos discursos efusivos de seu Führer. Faltava algo para dar corpo a esse espírito criado e as Olimpíadas desempenhariam esse papel de maneira incontestável. Através dos Jogos, a Alemanha se mostrou renascida para os outros países e as grandes obras mostravam como o país tinha se refeito em tão pouco tempo, mas ao mesmo modo que orgulhava os alemães, amedrontava o mundo.

Pela primeira vez a tocha saiu da Grécia e foi para o país sede, em uma tentativa clara de demonstrar que os ideários gregos estavam se transferindo para o povo alemáo. Foi composto um hino olímpico, por Richard Strauss, especialmente para os jogos e no desfile de abertura colocou-se, também pela primeira vez, as delegaçóes em ordem alfabética, e estas, em sua grande maioria, faziam a saudação a Hitler ao passar pela tribuna de honra onde o ditador se localizava, mostrando que os nazistas estavam conseguindo o que queriam.

Esse evento foi organizado em seus minimos detalhes com vistas a ser um marco do renascimento do país frente ao mundo. O público compareceu em massa aos jogose um dos momentos polêmicos foi quando membros de algumas delegaçôes no desfile de abertura fizeram uma saudação a Hitler, que foi interpretada como um sinal de simpatia ao regime, fato aproveitado pela imprensa alemã para publicidade. (SALUN, 2012, p.9)

Os jornais da época eram controlados pelo Governo e qualquer noticia não favorável era violentamente reprimida dentro da própria redação. $\mathrm{O}$ rádio também estava a favor do regime e sob sua intensa vigilância. Apenas os esportes em que os nazistas tinham chances de medalha eram exaltados pelas propagandas. O futebol, por exemplo, perdeu espaço na mídia quando a seleção foi derrotada na segunda rodada para a Noruega por 2 a 0 e acabou eliminada. Falhar dentro dos jogos era uma derrota do povo alemão.

A cobertura midiática dos Jogos foi a mais intensa até então. Mais de 300 estaçôes de rádio transmitiram os Jogos em mais de 25 idiomas. Estes foram os primeiros Jogos transmitidos pela televisão, ainda que apenas em Berlim. William Dodd, embaixador norte-americano na Alemanha, descreveu que a propaganda, apesar de ter surtido efeitos junto da opiniáo pública local, desagradara aos estrangeiros. 
150 mil pessoas assistiram aos Jogos em 28 salas de transmissão espalhadas pela capital. As salas de cinema funcionavam como a televisão de hoje. Era o grande veículo audiovisual nos anos 30. Calcula-se que tenham sido produzidos 1.350 longas-metragens nos doze anos de domínio do partido nazista. Quarenta mil escolas, de um total de 62 mil, espalhadas pelo território alemáo, dispunham de salas de projeção. (FERREIRA, 2002). A imagem que queriam passar dos jogos era feita através delas e por esse motivo vamos analisar o filme encomendado por Hitler a Leni Riefenstahl sobre os Jogos Olímpicos de 1936.

Como o corpo ariano estava em evidência nos jogos, as imagens seriam fundamentais para sacramentar a ideia deste corpo como o perfeito, como o triunfo de um regime e de uma ideologia.

A versão cinematográfica dos Jogos Olimpicos, feita por Leni Riefenstahl, corrobora
ainda mais esta epifania: ela dá vida ao simbólico eproporciona aos alemäes a celebração
dos seus ideais. (...) O corpo em Olympia é o elemento central. Ele é o ponto de partida
para entender a obsessáo dos nazistas pela supremacia da raça, para explicitar porque
os gregos se tornaram tão caros aos alemäes e, finalmente, para propor analogias entre
as competiçốes olimpicas e a guerra. (FERREIRA, 2002, p.7)

O filme foi dividido em duas partes: a primeira, chamada Fest der Völker ( Festa do Povo), começa mostrando a Grécia antiga e a chama olímpica sendo acesa e indo para a Alemanha, insinuando que somente um povo predestinado como o alemão poderia resgatar os originais jogos gregos. A Festa do Povo enfatiza o Atletismo, modalidade que mais incorpora e se aproxima dos jogos que os gregos praticavam. O filme é uma verdadeira escola e modelo para todas as transmissóes esportivas que temos hoje. Ele consegue mostrar o atleta, sua expressáo de dor, cansaço e, ao mesmo tempo, se remeter à plateia, ao delírio do público. Os cortes de imagem nos fazem achar que estamos assistindo a uma transmissão atual, inclusive com a câmera lenta. "É inegável a contribuição que as filmagens de Leni ofereceram às atuais transmissóes. O padrão de imagens pode ser medido na cobertura que ela deu aos esportes coletivos como o hóquei, o pólo e o futebol." (FERREIRA, 2002) É claro que as bandeiras e hinos olímpicos têm seu espaço no filme, mas a colocação das bandeiras nazistas em todo estádio nos lembra, a todo o momento, que aquele espetáculo de imagens é feito pelos nazistas. E, se existia alguma dúvida sobre essa afirmação, ela é ratificada nas vezes em que Hitler aparece como espectador e amante dos jogos, mas sem deixar de mostrar, com seu uniforme militar e a suástica no braço, que ele é o comandante daquela Nação. Olympia consegue passar a idéia de que guerrear é bom e sua data de estréia, 20 de abril de 1938, caía como uma luva para convencer o povo germânico do conflito prestes a iniciar-se.

Esse filme, um dos mais polêmicos da história do cinema, já despertou debates das mais diversas naturezas, indo desde a questão politica do envolvimento de cinema e esporte com determinados regimes totalitários, passando pelas questóes éticas do papel dos cineastas no forjar de representaçóes sociais, chegando também às questóes estéticas, pois Leni teve de criar mecanismos técnicos para permitir capturar em toda a plenitude os gestos esportivos, bem como inovou nas tomadas de planos inusitados. (MELO, 2005, p.58) 
A segunda parte chamada Fest der Schönheit, Festa da Beleza, mostra os atletas brancos, loiros, de olhos azuis em meio à natureza, ressaltando seus corpos e fazendo uma analogia ao povo alemáo, mostrando o que Huizinga (2001:55) afirma: "A partir do momento em que um jogo é um espetáculo belo, seu valor cultural torna-se evidente”. E para a cultura alemã o esporte era, como vimos, um fator de disciplina e superação do indivíduo. Através do corpo belo ariano, o povo alemáo cumpria seu papel histórico e isso era difundido na propaganda nazista. O filme de Leni está entre os mais notórios e bem sucedidos casos de propaganda do século XX e se encaixou em tudo aquilo que a propaganda nazista pretendia com os Jogos Olímpicos. Em Olympia, "o tratamento dado ao esporte é o de um ritual, de realizaçôes heróicas de super-homens, o que representa um elemento da filosofia nazista."(HOLMES, 1974, p.175)

É o muito mais que um simples documentário - é um hino de exaltação à Alemanha
nazista, através da glorificaçấo da força física, da saúde e da pureza racial, miticamente
fotografadas. Foram necessários 800 mil metros de filme rodados para mostrar, através
do sacrifício individual de cada atleta, como essa força e essa energia forjavam a nação,
aceitas pelo sacerdote intermediário, o Führer (LENHARO, 2003, p.60)

A presença do recorde no esporte também fazia analogia ao que o povo alemão vivia naquela época. $\mathrm{O}$ mais rápido, quanto mais veloz, melhor, a superação física do atleta mostrava a rapidez com que o povo alemão queria e estava conseguindo se reerguer e principalmente impulsionar sua indústria bélica. A "guerra relâmpago", a Blitzkrieg alemã, que foi o fator chave para o sucesso nos primeiros anos da Segunda Guerra Mundial, mostrou isso.

Para inflamar os jovens o jornal BV (BlumenauerVolkskalender), por exemplo, buscava sempre se remeter aos heroísmos praticados pelos alemães na Primeira Guerra Mundial. A comparação era clara entre os jovens que lutaram na década de 10 e os jovens da década de 30, jovens que deram a vida à Nação sempre enfatizando o amor à Pátria e o sacrifício ante o inimigo para a defesa da Pátria.

Outro fator que a mídia introduziu nestes Jogos Olímpicos foi a divulgação de um "quadro de medalhas". Ora, se os alemães queriam demonstrar para o mundo que tinham renascido através dos jogos, tinham que demonstrar com fatos que eram os vencedores dos Jogos Olímpicos. Como afirma Huizinga (2001, p.57) "em todos os jogos, é muito importante que o jogador possa gabar-se a outros de seus êxitos”. A Alemanha se gabou através do "quadro de medalhas" e reforçou a propaganda nazista de um Estado forte e superior ao mundo. "O desejo inato de ser o primeiro continuará levando os grupos de poder a entrar em competição" (HUIZINGA, 2001, p.87). Os Jogos foram uma "guerra" que os alemães venceram e inflaram a sua autoestima para a verdadeira guerra que estava por vir.

Segundo Gastaldo (2012), muito do desencanto do pensador holandês Huizinga com o esporte como forma moderna de jogo vem do uso dos Jogos de Berlim como propaganda nazista. "Homo Ludens é um livro de seu tempo: faz em vários momentos uma crítica direta a todos os regimes totalitários e ao uso perverso que estes fizeram do esporte"(GASTALDO, 2012, p.127) 
No entanto, por mais que tenha mostrado ao mundo suas grandes construções, a bela organização e a superioridade alemã no "quadro de medalhas" dos Jogos, o nazismo levou um golpe contra o qual nada pode fazer a náo ser se silenciar como fez seu chefe Hitler ao sair do Estádio Olímpico. O golpe se chamava Jesse Owens. Americano e negro, Owens conquistou 4 medalhas de ouro no atletismo, nos 100 metros, 200 metros, 4x100 metros e no salto em distância. Nessa última modalidade, derrotando o campeão europeu e alemão favorito ao ouro Luz Long, no último salto e superando o recorde olímpico. Justamente dentro do esporte que, como já dissemos, mais se assemelha com os antigos jogos gregos e que Hitler tinha como questão de honra a vitória para mostrar a superioridade do povo alemão e do corpo bélico nazista. Esse desejo não foi alcançado por Hitler, mas a propaganda nazista explorou ao máximo os Jogos mostrando o seu poderio militar, capacidade de organização e ambição do povo alemão em ser o melhor. Além disso, demonstrou como o esporte e um evento esportivo da magnitude dos Jogos Olímpicos pode ser um trunfo político.

\section{Considerações Finais}

Os Jogos de Berlim se tornaram famosos pela propaganda nazista que enxergou no esporte uma arma para difundir seus ideais. Foi a primeira vez que isso aconteceu de forma tão aguda em uma Olimpíada, mas não foi a última. Após Berlim 1936, os jogos foram paralisados em virtude da Segunda Guerra Mundial. Muito se diz que, em 1936, o clima já era de guerra iminente na Europa e a propaganda nazista em torno do corpo bélico e do esporte usado como guerra nos mostra que sim. Mas, desde 1948, quando os Jogos voltaram a ser realizados, dessa vez em Londres, eles não deixaram de ser políticos nem de promover culturas e sistemas político-sociais.

Em mais de 100 anos de existência, o Movimento Olímpico da Era Moderna
também dá mostras de uma relaçâo próxima com a dinâmica da sociedade e,
apesar do Comitê Olímpico Internacional (COI) declarar-se apolítico, ele se viu
envolvido em situaçóes extra-esportivas que alterou seus rumos e determinou novas
concepçóes. RUBIO, 2012, p.3)

A polaridade entre EUA e URSS que disputavam a hegemonia mundial no pós-guerra, fez os Jogos se tornarem um reflexo dessa disputa (Tubino:2006). Até o "quadro de medalhas" inaugurado por Hitler, já teve sua alteração a gosto dos interesses de grandes potências, com o ouro valendo mais que prata e bronze para os americanos vencerem os Jogos.

Vencer os Jogos Olímpicos se tornou uma grande propaganda de um regime ou um Governo para todo o mundo. Isso se tornou tâo evidente que o Comitê Olímpico Internacional, depois de grande tensão criada pela "Guerra Fria” nos Jogos Olímpicos, interviu e divulgou em 1990 uma Carta Olímpica com os principais pontos: 
- Não haverá discriminação racial, religiosa ou política contra qualquer país ou pessoa participante dos jogos;

- Não serão atribuídos pontos e não será determinada uma nação como vencedora dos Jogos Olímpicos;

- Não será permitida qualquer propaganda ou manifestação de cunho político, religioso ou racial. (COI apud SIGOLI; DE ROSE, 2004, p.118)

A propaganda nazista conseguiu alguns de seus objetivos, mas o esporte se encarrega de provar algumas coisas ao homem, como provou aos nazistas, que um negro como Jesse Owens era melhor do que um ariano, escrevendo um dos melhores capítulos da história do esporte. Depois dos alemães exaltarem seu regime através dos Jogos em 1936, os americanos já se utilizaram disso, assim como os soviéticos e recentemente os chineses. Isso mostra a importância que o esporte tem dentro da nossa sociedade e caminha junto com a política.

\section{Referências Bibliográficas}

DAMATTA, Roberto. Carnavais, malandros e heróis. Rio de Janeiro: Zahar, 1979.

FERREIRA, Fernanda Martins. Olympia, o triunfo do corpo. UFJF. Facom $2^{\circ}$ sem 2002.

GASTALDO, Edison. Homo Ludens e o Esporte Moderno. In: Esporte na idade Mídia: diversão, informação e educação. Org. MORAIS, Osvando J. de; MARQUES, José Carlos. São Paulo: INTERCOM, 2012.

GRÜTZMANN, Imgart. Lugares e memórias na propaganda nacional-socialista do Blumenauer Volkskalender (1933-1938) Estudos IberoAmericanos, v. 35, n. 1, 2009, p. 24-39. Pontifícia Universidade Católica do Rio Grande do Sul

HITLER, Adolf. Minha Luta. Berlim: Eher Verlag, 1925.

HOLMES, Judith. Olimpiada - 1936: glória do Reich de Hitler. História Ilustrada da 2a Guerra Mundial. Rio de Janeiro: Ed. Renes, 1974 (série conflito humano, v.3.)

HUIZINGA, Johan. Homo Ludens: o jogo como elemento da cultura. 5 ed. São Paulo: Perspectiva, 2001.

LENHARO, Alcir. Nazismo - “o triunfo da vontade”. 6. ed. São Paulo: Ática, 2003.

MANDELL, Richard D. The Nazi Olympics. Ballantine Books: New York, 1971.

MELO, Victor Andrade de. A presença do esporte no cinema: de ÉtienneJules Marey a Leni Riefenstahl. Rev. Bras. Educ. Fís. Esp., São Paulo, v. 19, n. 2, jun. 2005 . Disponível em <http://www.revistasusp.sibi.usp. br/scielo.php?script=sci_arttext\&pid=\$1807-55092005000200003\&lng $=$ pt\&nrm=iso $>$. acesso em 20 set. 2012. 
MURAD, Maurício. Jogos Olimpicos e politica um dia de setembro. In: Victor Andrade de Melo e Fabio de Faria Peres (org.) O esporte vai ao cinema. São Paulo: SENAC SP, 2005

RUBIO, Kátia. Jogos olimpicos da era moderna: uma proposta de periodização. Rev. bras. Educ. Fís. Esp., São Paulo, v. 24, n. 1, mar. 2010 . Disponível em <http://www.revistasusp.sibi.usp.br/scielo. php?script=sci_arttext\&pid=S1807-55092010000100006\&lng=pt\&nr $\mathrm{m}=\mathrm{iso}>$. acesso em 20 set. 2012.

SALUN, Alfredo Oscar. Esportes e propaganda politica na década de 1930. Contemporâneos Revista de Artes e Humanidades. Santo André, n.10 mai-out, 2012. Disponível em http://www.revistacontemporaneos. com.br/n10/artigos/esportes-propaganda-politica.pdf acesso em 20 set. 2012.

SIGOLI, M. A., DE ROSE JR., D. A história do uso politico do esporte. R. bras. Ci e Mov. 2004; 12(2): 111-119.

STACKELBERG, Roderick. A Alemanha de Hitler: origens, interpretaçôes, legados. Rio de Janeiro: Imago, 2002.

The Olympiad - Festival of the people. Hollywood selected video. North Hollywood, California: Timeless Video Inc., 1995, 115min., v. 64513.

The Olympiad - Festival of beauty. Hollywood selected video. North Hollywood, California: Timeless Video Inc., 1995, 97 min., v. 64523.

TUBINO, Manoel José Gomes. O que é o esporte. São Paulo: Brasiliense, 2006 